\title{
1 Optimization of the anaerobic co-digestion of pasteurized
}

\section{2 slaughterhouse waste, pig slurry and glycerine}

3 Ángela Rodríguez-Abalde ${ }^{\mathrm{a}, \mathrm{b}}$, Xavier Flotats $^{\mathrm{c}}$, Belén Fernández $^{\mathrm{a} *}$

4

5 a IRTA, GIRO Joint Research Unit IRTA-UPC. Torre Marimon, E-08140, Caldes de 6 Montbui, Barcelona, Spain.

$7 \quad{ }^{\mathrm{b}}$ EnergyLab, Edificio CITEXVI - Local 1, Fonte das Abelleiras, s/n, Campus

8 Universitario de Vigo, E-36310, Vigo, Spain.

$9{ }^{\mathrm{c}}$ GIRO Joint Research Unit IRTA-UPC. Department of Agrifood Engineering and 10 Biotechnology, Universitat Politècnica de Catalunya - BarcelonaTECH, Parc

11 Mediterrani de la Tecnologia, Building D-4, E-08860, Castelldefels, Barcelona, Spain.

$13 *$ Corresponding author contact details: e-mail: belen.fernandez@ irta.cat; phone: +34 $14934674040 ; \mathrm{Fax}+34938650954$. 


\section{Introduction}

The increasing demand of renewable energy sources and reuse of wastes require good technological solutions, following current European regulations and state member policies. Biogas is a form of renewable energy produced from biomass by the anaerobic digestion (AD) process. The biogas is used to produce electricity, heat or as transport fuel (De Vries et al., 2012). Main substrates for AD include agricultural biomass in the form of animal manures, energy crops (e.g. maize) and organic residues from the processing industry (e.g. glycerine, beet tails, animal wastes, fruit pulp wastes). The use of animal manure and other organic wastes as bioenergy feedstock would allow farmers to take profit of new economic markets for traditional waste products. Livestock wasteto-bioenergy technologies, as $\mathrm{AD}$, have the advantage to convert the treatment of livestock waste from a cost into a profit that can diversify farm incomes.

Nonetheless of the interesting environmental advantages of the livestock waste treatment by $\mathrm{AD}$, as the greenhouse gases emissions reductions, biogas production using only animal manure is not economically sustainable, and addition of biomass from other sources is needed (Møller et al., 2007). The livestock co-digestion with other organic waste sources, combined with good manure management practices, have shown an improvement in the economic feasibility in many individual or centralized agrobiogas installations.

The successful of the co-digestion strategies resides in the selection of co-substrates that must be showing complementary characteristics. Pig manure (PM) is characterized by a high buffer capacity and contains a wide variety of micro and macronutrients necessary for the growth and activity of anaerobic microorganisms, but shows high ammonium concentration and low organic matter content (Hartmann and Ahring, 2006). Several positive experiences have been described about the co-digestion of pig manure with 
complementary substrates as algae, food wastes or catch crops (Astals et al., 2015;

Dennehy et al., 2016; Molinuevo-Salces et al., 2015).

The co-substrates selection depends on their geographic availability in the area where the biogas plant is located, which, at the same time, is related with the kind of agro-food industry economy developed in this area. In the case of Catalonia, the meat sector is of great importance, being also one of the top five industries in Spain (Blancafort, 2009). This sector generates large quantities of materials not intended for human consumption, so called animal by-products (ABP). Besides animal food or meat and bone meal production, $\mathrm{AD}$ is one of the allowed methods to valorise these products (European Community, 2009 and 2011). Due to their composition, mainly composed by proteins and lipids with variable water content (Rodriguez-Abalde et al., 2011), ABP are considered good substrates for the AD process, according to the high methane yield potential. Although inhibitory processes could take place because of the combined release of ammonia due to protein decomposition and long chain fatty acids (LCFA) coming from fat degradation (Wang et al., 2016; Chen et al., 2008). ABP co-digestion strategy could reduce inhibition phenomena, and allows the progressive acclimatization of the bacteria to specific inhibitors such as ammonia (Edström et al., 2003) and/or LCFA (Silvestre et al., 2011), thus facilitating the control of the anaerobic process. In the last decade, other organic substrate, generated in huge quantities, is the recovered glycerine $(\mathrm{RG})$ generated as by-product of the biodiesel manufacturing industry. The biodiesel production in the European Union has increased from 500,000 tons in 1998 to 9,000,000 tons in 2009 (EBB, 2010). Each tone of biodiesel generates 0.1 tone of RG. The RG contains different components (alcohols, water, inorganic salts, free fatty acids, un-reacted triglycerides and methyl esters) that required removal from the RG before used as a raw material for alimentary, cosmetic or drug industry. The purification step 
might be economically unfeasible for most biodiesel plants, being their energy valorisation by $\mathrm{AD}$ an attractive option (Castrillon et al., 2011, Fountoulakis et al., 2010). Since glycerine is characterized by low nitrogen content and high organic matter concentration, the co-digestion with rich nitrogen organic waste, as the $\mathrm{PM}$ or $\mathrm{ABP}$ wastes, could be an adequate strategy to limit the risk of organic overloading of their anaerobic mono-digestion (Astals et al., 2012; Robra et al., 2010).

Most studies about co-digestion are based in the use of two substrates, although there are several experiences with ternary mixtures such as tomato residues with corn stover and dairy manure (Li et al., 2016), manure with food waste and sewage sludge in a proportion of 70:20:10 (Marañon et al., 2012) or cattle manure and food waste supplemented with crude glycerine (Castrillón et al., 2013). As an innovation aspect of this study, the results of ternary mixture co-digestion using pig manure, slaughterhouse and recovered glycerine are shown. The tertiary mixtures analysed have been designed based on the $\mathrm{C} / \mathrm{N}$ ratio.

The aim of this study is to investigate the effect of adding recovered glycerine from biodiesel manufacturing during the continuous co-digestion of pig manure and slaughterhouse waste as strategy to balance the $\mathrm{C} / \mathrm{N}$ ratio. The study includes the analysis of the effect of binary and tertiary mixtures on the biogas productivity and the stability of the process in terms of intermediary compounds as the volatile fatty acids and ammonia.

\section{Material and methods}

\subsection{Wastes \& inocula}

PM was collected from a centralized manure treatment facility located in Lleida (Spain). Fourteen fresh manure samples were collected (approximately every 3 months) and characterized, in order to account the temporal variability (seasonal fluctuations, 
changes in pig slurry management, etc.). The first sample was used for batch tests, while all samples were characterized and used as feedstock for the continuous AD experiment.

Slaughterhouse waste (ABP) came from a pig slaughterhouse facility located in Barcelona (Spain). They consisted of a mixture of internal organs (kidney, lungs, livers and hearts, reproductive organs and fatty fractions), all classified as ABP type 3 (European Community, 2009 and 2011). All fractions were minced using an industrial mincer till a particle size of $4 \mathrm{~mm}$, mixed and pasteurized at $70^{\circ} \mathrm{C}$ during 60 minutes, following European ABP regulations (European Community, 2009 and 2011). The pasteurization was done in a high pressure and temperature autoclave (Iberfluid Instruments, Spain). Three pasteurized ABP (PP-ABP) were used along the experiments: one for characterization and batch tests (BMP) and other two as feedstock of the digester.

Enough quantity of RG was collected once from the glycerol-containing waste discharge of a biodiesel factory located in Barcelona (Spain) and used for characterization, batch tests and feedstock of the digester. All materials, PP-ABP, PM and RG, were frozen till being used.

The inoculum used in the batch test corresponds with the anaerobic sludge sampled in a wastewater treatment plant (WWTP) located in Barcelona. The inoculum used in the continuous experiment was a mixture (ratio 4:1, expressed as \% volume) of digested sewage sludge, collected in the same WWTP as the inoculum for batch experiment, and the effluent of a mesophilic pig manure anaerobic digester (Lleida, Spain).

\subsection{Analytical methods}

Usual parameters were measured according to Standard Methods (APHA, AWA, WEF, 2005): total and volatile solids (TS, VS), pH, alkalinity ratio (AR), total 
115 Kjeldhal nitrogen (TKN), total ammonium nitrogen (TAN) and sulphate $\left(\mathrm{SO}_{4}{ }^{2-} \mathrm{S}\right)$.

116 Total carbon (TC) and total nitrogen (TN) were determined by elemental analysis

117 (Leco, USA). Total chemical oxygen demand (COD) was determined by a modified

118 Standard Methods procedure (Noguerol-Arias et al., 2012). Free ammonia (FAN)

119 content was calculated using the formula given by Hansen et al. (1998). Proteins

120 were calculated by multiplying the organic nitrogen by $6.25 \mathrm{~g}_{\text {protein }} \mathrm{g}^{-1}$ Norg factor

121 (Gelegenis et al., 2007). The fat content was analysed following recommendations of 122 n-hexane extractable material for sludge, sediment and solid samples method of EPA 123 (2005). Volatile fatty acids (acetic, propionic, i-butyric, n-butyric, i-valeric, n-valeric, 124 i-caproic and n-caproic acids) were determined by gas chromatography (VARIAN 125 CO-300) with a flame ionisation detector (FID) and a capillary column (TRB-FFAP 126 de $30 \mathrm{~m} \times 0.32 \mathrm{~m} \times 0.25 \mu \mathrm{m})$. The carrier gas was helium $\left(2 \mathrm{ml} \cdot \mathrm{min}^{-1}\right)$. Biogas composition $\left(\mathrm{CH}_{4} / \mathrm{CO}_{2}\right)$ was determined by gas chromatography. The $\mathrm{CH}_{4}$ and $\mathrm{CO}_{2}$ were determinate with a packed column (Varian Haysep-Q 80-100 MESH 2mm x $\left.1 / 8^{\prime \prime} \times 2 \mathrm{~mm} \mathrm{SS}\right)$. The carrier gas was helium $\left(2 \mathrm{ml} \cdot \mathrm{min}^{-1}\right)$. The injector and column temperature were $250{ }^{\circ} \mathrm{C}$ and $105^{\circ} \mathrm{C}$ respectively.

\subsection{Biochemical methane potential tests}

The mesophilic anaerobic biodegradability $(\mathrm{AB})$, expressed as a percentage of the total COD and calculated according to Soto et al., (1993), of every waste was determined by triplicate through biochemical methane potential (BMP) tests. Glass vials of 1.21 were filled with $0.5 \mathrm{~kg}$ of a solution composed by the inoculum $\left(5 \mathrm{gvss}_{\mathrm{Vs}} \mathrm{l}^{-1}\right)$, the substrate (initial concentration of $\left.5 \mathrm{~g}_{\mathrm{COD}} \cdot 1^{-1}\right)$, macronutrient solutions $\left(\mathrm{NH}_{4} \mathrm{Cl}, \mathrm{HPO}_{4} \mathrm{~K}_{2}, \mathrm{MgSO}_{4}\right.$, $\left.\mathrm{MgCl}_{2}\right)$, micronutrient solution $\left(\mathrm{H}_{3} \mathrm{BO}_{3}, \mathrm{ZnCl}_{2}, \mathrm{CuCl}_{2}, \mathrm{MnCl}_{2},\left(\mathrm{NH}_{4}\right)_{6} \mathrm{Mo}_{7} \mathrm{O}_{2}, \mathrm{CoCl}_{2}\right.$, $\mathrm{NiCl}_{2}, \mathrm{EDTA}, \mathrm{HCl}, \mathrm{NaSeO}_{3}$, resazurine $)$ and bicarbonate $\left(1 \mathrm{~g}_{\mathrm{NaHCO}} \cdot \mathrm{g}_{\mathrm{COD}}{ }^{-1}\right)$ as a buffer. 
of experimental time. Samples of gas from the headspace were taken periodically and measured by gas chromatography. Net methane volume, or total accumulated methane from vials minus the total accumulated methane from blanks, was used to calculate the maximum methane yields. All the cumulative methane yields were expressed under normal conditions $\left(0^{\circ} \mathrm{C}, 1 \mathrm{~atm}\right)$. Methane production and VFA concentration were expressed in COD equivalents, using the equivalence factors suggested by Angelidaki et al. (2009).

\subsection{Lab-scale digester set up}

A 61 semi-continuous stirred reactor tank was operated at $36 \pm 1^{\circ} \mathrm{C}$ for 70 weeks (490 days). The content of digester was continuously mixed using a mechanical stirrer. The temperature was maintained by recirculation of water through the double glass jacket of the tank. The digester was fed 4 times per day using a peristaltic pump and a temporized control system. The constant volume inside the digester was maintained using an overflow system. The biogas flow was measured by a displacement flowmeter (Ritter, Germany), after a silica bed to retain water vapour and a filter to avoid particles in the gas. The digester inlet and outlet flows, biogas flow and temperature were monitored daily, while main parameters $(\mathrm{pH}, \mathrm{AR}, \mathrm{COD}$ and VS concentration, $\mathrm{N}$ related compounds, VFA and biogas composition) were measured twice a week. All parameters were expressed as a weekly average.

The hydraulic retention time (HRT) and the organic loading rate (OLR) values were chosen since they are the design values of anaerobic digesters in centralized manure treatment facilities in Spain (Flotats et al., 2009). Based on industrial plant operation, the HRT was set in 20 or 33 days. The OLR was $0.8 \mathrm{~kg}_{\mathrm{COD}} \cdot \mathrm{m}^{-3} \cdot \mathrm{d}^{-1}$ along the acclimation period (P1) and between 2.2-3.2 $\mathrm{kg}_{\mathrm{COD}} \cdot \mathrm{m}^{-3} \cdot \mathrm{d}^{-1}$ for the others periods. The performance 
was divided in 3 stages based on feed composition, and in 5 periods based on HRT and OLR values.

For each period, the stability of the system was evaluated based on control parameters as specific methane yield $\left(\mathrm{Nm}_{\mathrm{CH} 4}^{3} \cdot \mathrm{kg}_{\mathrm{VS}}{ }^{-1}\right.$ and $\left.\mathrm{Nm}_{\mathrm{CH} 4}^{3} \cdot \mathrm{t}^{-1}\right)$, specific methane production rate $\left(\mathrm{Nm}^{3} \mathrm{CH}_{4} \cdot \mathrm{m}^{-3 \cdot} \mathrm{d}^{-1}\right)$, COD removal efficiency, methane content of the biogas, and VFA-related indicators. For that purpose taking into account the corresponding disturbance (change in feed composition), a "stable" system is defined as that with the $\geq$ methane production rate, methane yield and COD removal than in the reference condition, and when the alkalinity ratio and the propionic/acetic ratios are $\geq 0.4$ (Callaghan et al., 2002) and $\geq 1.4$ (Karthikeyan et al., 2016).

\section{Results and discussion}

\subsection{Characterization of organic substrates}

Table 1 shows the characterization of each waste, both for the initial samples used for batch tests and the samples used during the continuous experiments (14 and 3 samples of PM and PP-ABP, respectively). The PM showed similar characteristics along the experimentation. This fact is usual in agro-digesters due to the similar management practices at farm scale. Regarding the PP-ABP, the characterization was similar in the three analysed samples.

$\mathrm{RG}$ and PP-ABP were characterized by high COD content $\left(1,517\right.$ and $1,318 \mathrm{~g}_{\mathrm{COD}} \cdot \mathrm{kg}^{-1}$ respectively) in comparison with the PM $\left(45 \mathrm{~g}_{\mathrm{COD}} \cdot \mathrm{kg}^{-1}\right)$. The TS concentration showed great differences among the three substrates, being particularly low in PM, reason why this substrate was very suited as dilution media for the mixtures.

PP-ABP showed high TKN concentration, in accordance with their high TS concentration, being the $90 \%$ in form of organic nitrogen. The PM showed lower TKN and the $80 \%$ was in form of TAN concentration. The TKN concentration is in 
accordance with the proteins concentration that is a predominant compound in the PP$\operatorname{ABP}\left(110.6 \mathrm{~g} \cdot \mathrm{kg}^{-1}\right)$, while the PM showed low concentration and the proteins content is almost inexistent in RG. This glycerine was the unique waste with a relevant quantity of sulphates $\left(1.7 \mathrm{~g} \cdot \mathrm{kg}^{-1}\right)$. PP-ABP are also characterized by high fat concentration $(363.4$ $\left.\mathrm{g} \cdot \mathrm{kg}^{-1}\right)$, corresponding with the $50 \%$ of the VS. This high fat concentration makes ABP extremely prone to failure due to production of inhibitory compounds such as LCFA (Bayr et al., 2012). Firstly, lipids are hydrolysed to LCFA, which are oxidized to acetate and hydrogen through the $\beta$-oxidation pathway (Cirne et al., 2007; Mata-Alvarez, 2003). Inhibitory concentrations of individual LCFA vary depending on the fatty acid. Digesting anaerobically poultry slaughterhouse wastes and pig slaughterhouse waste with manure, LCFA were speculated to be the reason for process failure (Cuetos et al., 2010; Hejnfelt and Angelidaki, 2009).

The anaerobic biodegradability of PM, PP-ABP and RG was 41, 94 and $65 \%$ COD respectively (Table 1 ). The $\mathrm{PM}$ had a maximum methane yield of $0.2 \mathrm{Nm}_{\mathrm{CH} 4}^{3} \cdot \mathrm{kg}_{\mathrm{VS}}{ }^{-1}$, which was lower than $0.3-0.5 \mathrm{Nm}_{\mathrm{CH} 4}^{3} \mathrm{~kg}_{\mathrm{Vs}}{ }^{-1}$, the reported range in the literature for swine manure (Bernet and Béline, 2009; Grebrezgabher et al., 2010; Burton and Turner, 2003; Møller et al., 2004). The BMP of PM has a strong variability due to the presence of slowly biodegradable lignocellulosic materials (Møller et al., 2004), as well as because of the previous biodegradation of organic matter during manure storage (Rodriguez and Lomas, 2002). PP-ABP had a maximum methane potential yield of 0.9 $\mathrm{Nm}_{\mathrm{CH} 4}^{3} \cdot \mathrm{kg}_{\mathrm{Vs}}{ }^{-1}$, which was higher than $0.23-0.62 \mathrm{Nm}_{\mathrm{CH} 4}^{3} \cdot \mathrm{kg}_{\mathrm{Vs}}{ }^{-1}$ (Hejnfelt and Angelidaki, 2009), due to different fat and water contents. The obtained methane yield of $\mathrm{RG}$ was $202 \mathrm{Nm}_{\mathrm{CH} 4}^{3} \cdot \mathrm{t}^{-1}$, which is lower than the theoretical value of $1295 \mathrm{Nm}_{\mathrm{CH} 4}^{3} \cdot \mathrm{t}^{-1}$ for pure glycerine (Amon et al., 2006) but relatively close to $217-308 \mathrm{Nm}^{3} \mathrm{CH}_{4} \cdot \mathrm{t}^{-1}$, the reported potentials of glycerol fractions recovered by phosphate acidification or 
distillation processes (Siles et al., 2009). The presence of impurities (water, methyl ester, methanol, etc.) and inorganic salts (sulphate, phosphate, soda, etc.) depends very much on the biodiesel and/or glycerol recovery processes, being ultimately responsible for the decrease in methane yield as compared to pure glycerine. Figure 1 shows the accumulated methane curves of the three wastes (PM, PP-ABP and RG). No lag phase was reported for PM and RG, but a lag-phase of seven days was observed during the PP-ABP test with a sharply increase of methane production. This behaviour could be related with the high concentration of fat $\left(363.4 \mathrm{~g} \cdot \mathrm{kg}^{-1}\right)$ and LCFA (not determined), since an inhibition due to accumulated TAN or VFA was not observed. Silvestre et al., (2011) also observed that the long lag-phase observed during anaerobic digestion of trapped grease waste could be attributable to an adaptation or inhibition period for the microorganisms due to the high fat concentration.

\subsection{Reactor performance}

The PP-ABP, PM and RG were chosen because of their complementary composition, especially in relation to $\mathrm{C} / \mathrm{N}$ ratio that showed wide range among the three substrates: PM had the lowest $\mathrm{C} / \mathrm{N}$ ratio (5.7-5.3) and $\mathrm{RG}$ had the highest value (587.5), being PPABP in-between (14.1 - 15.7). Therefore, co-digestion mixtures were used stepwise to balance the $\mathrm{C} / \mathrm{N}$ ratio of the inlet flow to optimize the $\mathrm{AD}$ process, trying to be as close as possible to the optimal range (15-30). Although the optimum $\mathrm{C} / \mathrm{N}$ range has commonly been reported for an efficient use of nutrients and maximum methane yield in anaerobic digesters (Mshandete et al., 2004; Wu et al., 2010), lower $\mathrm{C} / \mathrm{N}$ ratios have also been suggested as optimal, particularly, in the anaerobic digestion of swine manure. In an early study, Sievers and Brune (1978) revealed that the optimal C/N range for swine manure digestion was $15-19$ in terms of maximum methane production. 
238 During the first step, the reactor feed content was only PM as substrate (P1); values

239 from this period were used as reference in terms of increment/ decrement of methane

240 yield or organic matter removal efficiency. In the second step (periods P2 and P3), two

241 different PM:PP-ABP mixtures were assessed, being PP-ABP the 7\% and 36\% inlet-VS

242 in P2 and P3, respectively. Finally, the co-digestion of two ternary mixtures (PM:PP-

243 ABP:RG) was assessed in the third step. Mean values of operational and control

244 parameters per period, as well as the ratio between theoretical methane potential of each

245 period and the experimental yield (named as $\alpha$ ), are shown in Table 2. The evolution of

246 the operational parameters (HRT and OLR) and specific methane production rate

247 through the different periods are shown in Figures 2 and 3a, respectively.

248 The first step and period (P1), with a feed composed by lonely PM with a C/N of 6.3,

249 was performed with 21 days of HRT and an OLR of $0.8 \mathrm{~kg}_{\mathrm{COD}} \cdot \mathrm{m}^{-3} \mathrm{~d}^{-1}$. The methane

250 production rate (Figure 3a), the methane yield and the methane production per ton of

251 fresh matter were $0.22 \mathrm{Nm}_{\mathrm{CH} 4}^{3} \cdot \mathrm{m}^{-3} \cdot \mathrm{d}^{-1}, 0.15 \mathrm{Nm}_{\mathrm{CH} 4}^{3} \cdot \mathrm{kg}_{\mathrm{SV}}{ }^{-1}$ and $3.6 \mathrm{Nm}_{\mathrm{CH} 4}^{3} \cdot \mathrm{t}^{-1}$,

252 respectively. The methane composition was $65 \%$ v/v. The TAN concentration (Figure

253 3b) was in the range of the optimal anaerobic digestion process, much lower than values

254 assumed as inhibitory (Yenigün and Demirel, 2013; Chen et al., 2008), with a FAN

255 level also below the inhibitory concentration of $0.45-1.1 \mathrm{~g}_{\mathrm{FAN}} \cdot 1^{-1}$ reported in the

256 literature (Angelidaki and Ahring, 1994; Hansen et al., 1998; Kayhanian, 1999).

257 VFA were used in this work as indicator for impending reactor failure. Different

258 indexes have been suggested as the most appropriate indicators for imbalance between

259 involved microbial groups: the content of propionic and/or branched-chain VFA (i-

260 butyric and i-valeric acids), or some ratios as the propionic to acetic or the VFA to total

261 alkalinity ratio are usually mentioned in previous works (Franke-Whittle at al., 2014;

262 Aymerich et al., 2013; Bruni et al., 2013). In this regard, the alkalinity ratio in P1 was 
below 0.4 (Figure 4a), or reference threshold (Callaghan et al., 2002), and the total VFA concentration in $\mathrm{P} 1$ was $0.3 \mathrm{~g} \cdot \mathrm{l}^{-1}$, indicating a stable performance. The acetic acid was the main VFA (> $50 \%$ total VFA) during this initial step. Isoforms of butyric acid and valeric acid, which usually are related to certain degree of unbalance in acetic production versus consumption rates (Aymerich et al., 2013), were found in minor quantities of $5 \%$ and $6 \%$ total VFA in this period (Figure $4 \mathrm{~b}$ ).

The second step had two PM:PP-ABP mixtures with a $\mathrm{C} / \mathrm{N}$ of 6.1 and 5.9 was divided in two periods, $\mathrm{P} 2$ and $\mathrm{P} 3$. In the $\mathrm{P} 2$, the OLR was increased from 0.8 till $3.0 \mathrm{~kg}_{\mathrm{COD}} \cdot \mathrm{m}^{-}$ ${ }^{3} \cdot \mathrm{d}^{-1}$ and consequently, the methane production rate, the methane yield and the methane production per ton rose to $0.47 \mathrm{Nm}_{\mathrm{CH} 4}^{3} \cdot \mathrm{m}^{-3} \cdot \mathrm{d}^{-1}$ (representing an increment of $+114 \%$ ), $0.35 \mathrm{Nm}_{\mathrm{CH} 4}^{3} \cdot \mathrm{kg}_{\mathrm{SV}}{ }^{-1}$ and $9.7 \mathrm{Nm}_{\mathrm{CH} 4}^{3} \cdot \mathrm{t}^{-1}$, respectively. Although the VFA concentration, mainly the acetic acid, increased to values close to $2 \mathrm{~g} \cdot \mathrm{l}^{-1}$ (Table 2) and the TAN and FAN concentrations increased to 2.95 and $0.33 \mathrm{~g}_{\mathrm{N}} \cdot \mathrm{l}^{-1}$, respectively (Figure $3 \mathrm{~b}$ ), the system was considered stable due to the constant gas production along time. The $\mathrm{CH}_{4}$ content also increased from $65 \%$ to $73 \% \mathrm{v} / \mathrm{v}$. This general increment of control parameters was related to the higher lipid concentration of the feeding mixture, following previous works as Silvestre et al., (2011) who observed adaptation of the anaerobic biomass and an increase in the methane yield, after the addition of grease to the sewage sludge AD. Although the increment of the concentration of total VFA in the reactor, the concentration of i-butyric, n-butyric and i-valeric acids were slightly similar as in P1 but showing a relative distribution in P2 lower than in P1 (Figure 4b).

In period P3, the HRT was increased to 33 days to prevent a potential inhibition by TAN or LCFA due to the increment of PP-ABP percentage in the feeding mixture, since higher HRT than 20 days might facilitate the biomass adaptation in manure anaerobic digesters (Murto et al., 2004; Salminen and Rintala, 2002). The OLR applied in this 
288

289

290

291

292

293

294

295

296

297

298

299

300

301

302

303

304

305

306

307

308

309

310

311

312

period was reduced to $2.6 \mathrm{~kg}_{\mathrm{COD}} \cdot \mathrm{m}^{-3} \cdot \mathrm{d}^{-1}$ and, in accordance, the methane production rate decreased regarding P2. Nevertheless, the methane yield increased from 0.35 until 0.43 $\mathrm{m}^{3} \cdot \mathrm{kg}_{\mathrm{VS}}{ }^{-1}$ and the methane production per ton achieved was $13.6 \mathrm{Nm}_{\mathrm{CH} 4}^{3} \cdot \mathrm{t}^{-1}$. Once again, the system reached a stable performance: the methanogenesis was not affected by the VFA concentration, since the system was correctly buffered as the alkalinity ratio showed $(<0.4)$, while the $\mathrm{CH}_{4}$ content and yields, TAN and FAN levels were similar to the values obtained in the P2. The content of acetic acid increased but the VFA profile was almost similar to P2 (Figure 4b). Moreover, the decrement of valeric acid isoforms (4-5\% and $\leq 1 \%$ total VFA in $\mathrm{P} 2$ and $\mathrm{P} 3$, respectively), which are usually related with delayed or incomplete protein degradation (Bruni et al., 2013), was shown along this step. In this sense, this indicated that the system evolved to a more balance substrate degradation.

In fact, the methane yield at the end of the second step $\left(0.43 \mathrm{Nm}^{3} \mathrm{CH} 4 \cdot \mathrm{kg}_{\mathrm{VS}}{ }^{-1}\right)$ was higher than previously reported values of $0.27-0.35 \mathrm{Nm}^{3} \mathrm{CH}_{4} \cdot \mathrm{kg}_{\mathrm{VS}}{ }^{-1}$ during the co-digestion of slaughterhouse waste with pig manure and fruits (Álvarez and Liden, 2008) or 0.38 $0.43 \mathrm{Nm}^{3}{ }_{\mathrm{CH} 4} \cdot \mathrm{kg}_{\mathrm{SV}}{ }^{-1}$ with sewage sludge (Luste and Luostarinen, 2010). Another positive effect observed in this second step was a synergy effect over methane production measured through the $\alpha$ index (Table 2): methane production in P2 and P3 was 1.4 and 1.0 times, respectively, the theoretical value calculated considering the maximum methane potential obtained with batch tests.

Ternary mixtures were tested in the third step, being co-substrates up to 16 and 18 \%inlet-VS in periods $\mathrm{P} 4$ and $\mathrm{P} 5$, respectively. Therefore, the OLR and $\mathrm{C} / \mathrm{N}$ ratio were increased to 2.5 and $3.2 \mathrm{~kg}_{\mathrm{COD}} \cdot \mathrm{m}^{-3} \mathrm{~d}^{-1}$, and to 8 and 10 (Figure 3a) in $\mathrm{P} 4$ and $\mathrm{P} 5$, respectively. A clear change in the total VFA content, equivalent to $4.2 \%$ of the outletCOD, and profile was found. The highest propionic/acetic ratio was attained in this 
period, but the mean value per period was below 1.4 or value reported as inhibitory ratio

314 (Karthikeyan et al., 2016). The acetic and propionic acids were the main VFA, while ibutyric and i-valeric acids almost disappeared (Figure 4b). Both methane yield and production rate improved in $+23 \%$ and $+11 \%$ in $\mathrm{P} 4$ with respect to $\mathrm{P} 3$, reaching a COD removal efficiency of $51 \%$. Related to the pig manure period or P1, the achieved methane yield and the methane production per ton, increased $+153 \%$ and $+344 \%$ in $\mathrm{P} 4$, respectively.

Finally, in period P5, the system recovered a low concentration of VFA (1.9\% outletimproved COD removal efficiency of $55 \%$ also pointed out such balanced situation in P5. The propionic/acetic ratio clearly decreased (Figure 4a) and minority VFA, as lineal and branched butyric and valeric acids, were not detected. Consequently, the occurrence of an imbalance between the different bacterial groups of acidogens and acetogens which might take place in the co-digestion of PM:PP-ABP blends were prevented with this tertiary mixture.

Regarding AD systems and RG, Mata-Alvarez et al., (2000) and Rétfalvi et al., (2011) found high amounts of VFA that were released rapidly to the medium, while the inhibitory effect on methanogenesis of propionic acid with concentrations in-between 1$6 \mathrm{~g} \cdot 1^{-1}$ after intermittently glycerine additions. Angelidaki et al., (1998) assumed that glycerol biodegradation to propionate took place instantly, similarly to Fountoulakis et al., (2010) who observed that glycerol biodegradation took place at a faster rate than that of propionate, and suggested that a glycerol overload was responsible of an increased propionate concentration in the reactor. In this work, a maximum dose of $18 \%$ inlet-VS was reached without failure, while Amon et al., (2006) found that glycerine addition higher than 8-15\% inlet-VS caused a decrement on biogas and methane yields 
in pig manure and maize silage co-digestion systems. These authors obtained an increment of $+19 \%$ in methane yield (from 0.57 to $0.68 \mathrm{Nm}^{3} \mathrm{CH}_{4} \cdot \mathrm{kg}_{\mathrm{Vs}}{ }^{-1}$ ) when glycerine was $6 \%$ inlet-VS.

The buffer capacity of the digester was found to be a key aspect to overcome the accumulation of VFA after glycerine addition: in parallel with the propionic acid accumulation, the highest values of $\mathrm{pH}(7.8-8.0)$ and alkalinity ratio $(0.24)$ were reached in P5. Although total alkalinity content decreased (Table 2) due the reduced quantity of PM in the tertiary mixture, there was enough buffer capacity despite ammonia concentration in periods P4 and P5 was lower than in the previous periods (Figure 3b). This alkalinity ratio is consistent with other works that reported buffer capacity changes due to the accumulation of inorganic salts in the digester (Siles et al., 2009).

Regarding synergism of tested tertiary mixtures, no effects were observed since $\alpha$ index was 0.7 in both periods P4 and P5 (Table 2). This result was contrary to Fountoulakis et al., (2010) who concluded that the growth of active biomass was enhanced after crude glycerol addition at $1 \% \mathrm{v} / \mathrm{v}$ in sewage sludge co-digestion digesters that also might increase the $\mathrm{CH}_{4}$ production above the expected theoretical value. Opposite to this, Silvestre et al., (2015) stated, after studying the addition of crude glycerine to sewage sludge, that the added quantity of glycerine is highly dependent on the characteristics of the main waste. Although this, the system was considered stable since methane yield did not decrease $\left(0.38 \mathrm{Nm}^{3} \mathrm{CH}_{4} \cdot \mathrm{kgVs}^{-1}\right)$. Based on these results, synergism and stability not always appear together; additionally, the methane production per ton of fresh matter achieved the highest value $\left(18.7 \mathrm{Nm}_{\mathrm{CH} 4}^{3} \cdot \mathrm{t}^{-1}\right)$ in this last period. 


\section{Conclusions}

362 A continuous experiment of 490 days for the co-digestion in mesophilic conditions of binary and tertiary blends of PM, PP-ABP and RG was performed successfully. A slow stepwise increment of $\mathrm{C} / \mathrm{N}$ ratio from 6 (PM alone) to 8-10 (tertiary blends) enhanced the methane yield and production rate, without process failure. The best methane production rate were obtained upon a glycerine addition of $16 \%$ inlet-VS in period P5, reaching $0.64 \mathrm{Nm}_{\mathrm{CH} 4}^{3} \cdot \mathrm{m}^{-3} \cdot \mathrm{d}^{-1}$ or 2.9-fold the initial one $\left(0.22 \mathrm{Nm}_{\mathrm{CH} 4}^{3} \cdot \mathrm{m}^{-3} \cdot \mathrm{d}^{-1}\right.$ with PM solely). Such improvement was not explained because an activity enhancement or synergism effect, but because of a more balanced degradation process due to unstressed bacterial populations, as the VFA-related indicators showed through the performance, due to the applied $\mathrm{C} / \mathrm{N}$ adjustment. The buffer capacity of the system while digesting tertiary blends also played an important role to overcome imbalance. Such situation was also reflected in the high specific methane yield attained especially in P6 with 18.7 $\mathrm{Nm}^{3} \mathrm{CH}_{4} \cdot \mathrm{t}^{-1}$, that represented an increment of $+414 \%$ regarding the period run with pig manure alone $\left(3.6 \mathrm{Nm}_{\mathrm{CH} 4}^{3} \cdot \mathrm{t}^{-1}\right)$. So, the co-digestion of tertiary blends of pasteurized animal by-products with pig manure and glycerine resulted in a feasible method of stabilization and valorisation of $\mathrm{ABP}$, based on the improved organic matter degradation, stress indicators and gas productivity. Finally, owing the $\alpha$ index value obtained and the increasing propionic to acetic ratio in the co-digestion of the tertiary mixture, further works should be addressed to study the performance of the reactor at higher retention times, in order to increase methane production, biomass adaptation and stability.

Acknowledgements 
387 Alvarez, R, Liden, G, 2008. Semi- continuous co-digestion of solid slaughterhouse waste, manure and fruit and vegetable waste. Renew. Energ. 33, 726-734. Amon, B, Kryvoruchko, V, Bodiroza, V, Pötsch, E, Zollitsch, W, 2006. Optimising methane yield from anaerobic digestion of manure: Effects of dairy systems and of glycerine supplementation. Int. Congr. Ser. 1293, 217- 220.

Angelidaki, I, Ahring, BK, 1994. Anaerobic thermophilic digestion of manure at different ammonia loads; effect of temperature. Water Res. 28 (3), 727-731. Angelidaki, I, Ellegaard, L, Ahring, BK, 1998. A comprehensive model of anaerobic bioconversion of complex substrates to biogas. Biotechnol. Bioeng. 63, 363-372. Angelidaki, I, Alves, M, Bolzonella, D, Borzacconi, L, Campos, L, Guwy, A, Jenicek, P, Kalyuzhnui, S, Van Lier, J, 2009. Defining the biomethane potential (BMP) of solid organic waste and energy crops: a proposed protocol for batch assays. Wat. Sci. Technol. 59, 927-934. APHA, AWWA, WEF, 1995. Standard methods for the examination of water and wastewater. American Public Health Association / American Water Works Association/Water Environment Federation. $19^{\text {th }}$ Ed., Washington DC, USA. Astals, S, Nolla-Ardèvol, J, Mata-Alvarez, J, 2012. Anaerobic co-digestion of pig 404 manure and crude glycerine at mesophilic conditions: biogas and digestate. Bioresour. Technol. 110, 63-70. recovery on co-digestion performance. Bioresour. Technol.181, 97-104. 

solids anaerobic digestion of agro-industrial waste and sewage sludge. Bioresour. Technol. 144, 107-114. anaerobic co-digestion of rendering plant and slaughterhouse wastes. Bioresour.

414 Technol. 104, 28-36.

Blancafort, J, 2009. Balance de la industria cárnica en 2008 y retos para 2009. Ganadería 59, 28-29.

Bernet, N, Béline, F, 2009. Challenges and innovations on biological treatment of livestock effluents. Bioresour. Technol. 100, 5431-5436.

Bruni, E, Ward, AJ, Kocks, M, Feilberg A, Adamsen AP, Jensen, AP, Poulsen, A. 2013. Comprehensive monitoring of a biogas process during pulse loads with ammonia. Biomass and Bioenergy 56, 211-220.

Burton, CH, Turner, C, 2003. Manure management — treatment strategies for sustainable agriculture. 2nd Ed. Silsoe Research Institute, Wrest Park, Silsoe, Bedford, 424 UK. 490.

425 Callaghan, F, Wase, DAJ, Thayanithy, K, Foster, CF, 2002. Continuous codigestion of cattle slurry with fruit and vegetable wastes and chicken manure. Biomass Bioenerg. 27, $71-77$.

Castrillón, L, Fernández-Nava, Y, Ormaechea, P, Marañón, E, 2011. Optimization of biogas production from cattle manure by pre-treatment with ultrasound and co-digestion 430 with crude glycerine. Bioresour. Techn. 102, 7845-7849.

431 Castrillón, L, Fernández-Nava, Y, Ormaechea, Quiroga G, 2013. Thermophilic codigestion of cattle manure and food waste supplemented with crude glycerin in induced bed reactor (IBR). Bioresour. Technol. 136, 73-77. 
434 Chen, Y, Cheng, JJ, Creamer, KS, 2008. Inhibition of anaerobic digestion process: a

435 review. Bioresour. Technol. 99, 4044-4064.

436 Cirne, DG, Paloumet, X, Björnsson, L, Alves, MM, Mattiasson, B, 2007. Anaerobic

437 digestion of lipid-rich waste-effects of lipid concentration. Renew. Eng. 32, 965-975.

438 Cuetos, MJ, Gómez, X, Otero, M, Morán, A, 2010. Anaerobic digestion and co-

439 digestion of slaughterhouse waste (SHW): Influence of heat and pressure pre-treatment

440 in biogas yield. Waste Manage. 30 (10), 1780-1789.

441 De Vries, JW, Vinken, TMWJ, Hamelin, L, De Boer, IJM, 2012. Comparing

442 environmental consequences of anaerobic mono- and co-digestion of pig manure to

443 produce bio-energy - A life cycle perspective. Bioresour. Technol. 125, 239-248.

444 Dennehy, C, Lawlor, P, G, Croize, T., Jiang, Y, Morrison, L, Gardiner, G, E, Zhan, X,

445 2016. Synergism and effect of high initial volatile fatty acid concentrations during food

446 waste and pig manure anaerobic co-digestion. Waste Manage. 56, 173-180.

447 Edström, M, Norberg, A, Thyselius, L, 2003. Anaerobic treatment of animal byproducts

448 from slaughterhouses at laboratory and pilot scale. Appl. Bioch. Biotechnol. 109, $127-$

44938.

450 EBB. 2010. http://www.ebb-eu.org/stats.phpanual. September 2010.

451 EPA, 2005. United States Environmental Protection Agency. Method 9071B. n-Hexane

452 estractable material (HEM) for sludge, sediment, and solid samples. Available at:

453 http://www.epa.gov/waste/hazard/ testmethods/sw846/pdfs/9071b.pdf

454 European Community, 2009. Regulation (EC) no 1069/2009 of the European

455 Parliament and of the Council of October 2009 laying down health rules as regards

456 animal by-products and derived products not intended for human consumption and

457 repealing Regulation (EC) No 1774/2002 (Animal by-products Regulation). 

25.

Flotats, X, Bonmatí, A, Fernández, B, Magrí, A, 2009. Manure treatment technologies:

On-farm versus centralized strategies. NE Spain as case study. Biores.Technol. 100 (22), 5519-5526.

Fountoulakis, M, Petousi, I, Manios, T, 2010. Co-digestion of sewage sludge with glycerol to boost biogas production. Waste Manage. 30, 1849-1853. Franke-Whittle, I, Walter, A, Ebner, C, Insam, H. 2014. Investigation into the effect of high concentrations of volatile fatty acids in anaerobic digestion on methanogenic communities. Waste Management, 34 (11), 2080-2089.

Gelegenis, J, Georgakakis, D, Angelidaki, I, Mavris, V, 2007. Optimization of biogas production by co-digesting whey with diluted poultry manure. Renewable En. 32, $2147-2160$.

Grebrezgabher, SA., Meuwissen, M, Prins, B, Oude, A, 2010. Economic analysis of anaerobic digestion - a case of green power biogas plant in The Netherlands. NJAS Wageningen J. Life Sci., 57, 2, 109-115.

Hansen, K, Angelidaki, I, Ahring, B, 1998. Anaerobic digestion of swine manure: inhibition by ammonia. Water Res. 32, 5-12. fraction of municipal solid waste: an overview. Wat. Sci. Technol. 53, 7-22. Hejnfelt, A, Angelidaki, I, 2009. Anaerobic digestion of slaughterhouse by-products.

479 Biomass Bioenerg. 33, 1046-1054.

480 Karthikeyan, O, P, Selvam, A, Wong, J, W, C, 2016. Hydrolysis-acidogenesis of food waste in solid-liquid-separating continuous stirred tank reactor (SLS-CSTR) for volatile organic acid production. Bioresour.Technol. 200, 366-373. 
Kayhanian, M, 1999. Ammonia inhibition in high-solids biogasification: an overview and practical solutions, Environ. Technol. 20, 355-365. Li, Y, Li, Y, Zhang, D, Li, G, Lu, J, Li, S, 2016. Solid state anaerobic co-digestion of tomato residues with dairy manure and corn stover for biogas production. Bioresour.Technol.217, 50-55. Luste, S, Luostarinen, S, 2010. Anaerobic co-digestion of meat-processing by-products and sewage sludge -Effect of hygienization and organic loading rate. Bioresour.Technol.101, 2657-2664. 2012. Co-digestion of cattle manure with food waste and sludge to increase biogas production. Waste Manag. 10, 1821-5. Mata-Alvarez, J, 2003. Fundamentals of the anaerobic digestion process. In: MataAlvarez, J. (Ed.), Biomethanation of the Organic Fraction of Municipal Solid Wastes. IWA Publishing, UK, 1-22.

Mata-Alvarez, J, Dosta, J, Macé, S, Astals, S, 2011. Codigestion of solid wastes: a review of its uses and perspectives including modeling. Critical Rev. Biotechnol. 31, 99-111.

Mata-Alvarez, J, Macé, S, Llabrés, P, 2000. Anaerobic digestión of organic solid wastes. An overview of research achievements and perspectives. Bioresour. Technol. 74, 3-16.

Molinuevo-Salces, B, Ahring, B, K, Uellendahl, H, 2015. Optimization of the CoOperation. Appl Biochem Biotechnol 175, 1710-1723. and solid fractions of manure. Biomass Bioen. 26, 485-495. 
Møller, HB, Nielsen, AM, Nakakubo, R, Olsen, HJ, 2007. Process performance of biogas digesters incorporating pre-separated manure. Livest. Sci. 112, 217-223. Mshandete, A, Kivaisi, A, Rubindamayugi, M, Mattiasson, B, 2004. Anaerobic batch codigestion of sisal pulp and fish wastes. Biores. Technol. 95, 19-24.

Murto, M, Björnsson, L, Mattiasson, B, 2004. Impact of food industrial waste on anaerobic codigestion of sewage sludge and pig manure. J. Environ. Man. 70, 101-107.

Noguerol-Arias, J, Rodríguez-Abalde, A, Romero-Merino, E, Flotats, X, 2012. Determination of Chemical Oxygen Demand in Heterogeneous Solid or Semisolid Samples Using a Novel Method Combining Solid Dilutions as a Preparation Step Followed by Optimized Closed Reflux and Colorimetric Measurement, Anal. Chem. 84, $5548-5555$.

Rétfalvi, T, Tukacs-Hájos, A, Albert, L, Marosvölgyi, B, 2011. Laboratory scale examination of the effects of overloading on the anaerobic digestion by glicerol. Bioresour. Technol. 102, 5270-5275.

Robra, S, Serpa, R, Oliveira, AM, Almeida, JA, Santos, JV, 2010. Generation of biogas using crude glycerine from biodiesel production as a supplement to cattle slurry. Biomass Bioenerg. 34, 1330-1335.

Rodriguez, A, Lomas, JM, 2002. Transition of particle size fractions in anaerobic digestion of solid fraction of piggery manure. Biomass Bioeng. 23, 229-235.

Rodríguez-Abalde A, Silvestre G, Fernández B, Flotats, X, 2011. Effects of thermal pre-treatments on solid slaughterhouse waste methane potential. Waste Manag. 31, $1488-1493$.

Salminen, E.A, Rintala, JA, 2002. Semi-continuous anaerobic digestion of solid poultry slaughterhouse waste: effect of hydraulic retention time and loading. Water Res. 36, 3175-3182. 
533 Sievers, D, Brune, D, 1978. Carbon / nitrogen ratio and anaerobic digestion of swine

534 waste. T. ASAE 21 (3), 537-549.

535 Siles, J, Martín, MA, Chica, A, 2009. Anaerobic digestion of glycerol derived from

536 biodiesel manufacturing. Bioresour. Technol. 100, 5609-5615.

537 Silvestre, G, Rodríguez-Abalde, A, Fernández, B, Flotats, X, Bonmatí, A, 2011.

538 Biomass adaptation over anaerobic co-digestion of sewage sludge and trapped grease

539 waste. Bioresour. Technol. 102, 6830-6836.

540 Silvestre, G, Fernández, B, Bonmatí, A, 2015. Addition of crude glycerine as strategy to

541 balance the $\mathrm{C} / \mathrm{N}$ ratio on sewage sludge thermophilic and mesophilic anaerobic co-

542 digestion. Bioresour. Technol. 193, 377-85.

543 Soto, M, Méndez, R, Lema, J, 1993. Methanogenic and non-methanogenic activity tests.

544 Theoretical basis and experimental set up. Water Res. 27, 1361-1376.

545 Wang, H, Fotidis, I, A, Angelidaki, I, 2016. Ammonia-LCFA synergetic co-inhibition

546 effect in manure-based continuous biomethanation process. Bioresour. Technol. 209,

$547 \quad 282-289$.

$548 \mathrm{Wu}, \mathrm{X}$, Yao, W, Zhu, J, Miller, C, 2010. Biogas and CH4 productivity by co-digesting

549 swine manure with three crop residues as an external carbon source. Bioresour.

550 Technol. 101, 404.

551 Yenigün, O., Demirel, B, 2013. Ammonia inhibition in anaerobic digestion: A review.

552 Process Biochem. 48, 901-911. 


\section{List of tables}

554 Table 1. Waste characterization. Nomenclature: PM, pig manure; PP-ABP, pasteurized 555 slaughterhouse waste; RG, recovered glycerine; $\mathrm{AB}$, anaerobic biodegradability; nd, not 556 detected; nm, not measured. Notes: *Mean values of all collected PM (14 samples) and 557 PP-ABP (3 samples) used in the continuous experiment. **Calculated value from 558 elemental analysis. ***Average yields of samples used in the continuous experiment.

559 Table 2. Mean values per period of operational and control parameters during the codigestion experiment. Nomenclature: PM, pig manure; PP-ABP, pasteurized slaughterhouse waste; $\mathrm{RG}$, recovered glycerine; $\alpha$ index, ratio between the theoretical methane potential and the experimental yield, both regarding each period. Note: *Conversion factors: $1.07 \mathrm{~g}_{\mathrm{COD}} \cdot \mathrm{g}_{\text {acetic }}{ }^{-1} ; 1.51 \mathrm{~g}_{\mathrm{COD}} \cdot \mathrm{g}_{\text {propionic }}{ }^{-1} ; 2.03 \mathrm{~g}_{\mathrm{COD}} \cdot \mathrm{g}_{\text {butyric }}{ }^{-1} ; 2.21$ $\mathrm{g}_{\mathrm{COD}} \cdot \mathrm{g}_{\text {valeric }}{ }^{-1} ; 2.34 \mathrm{~g}_{\mathrm{COD}} \cdot \mathrm{g}_{\text {heptanoic }}{ }^{-1}$ ) from Soto et al. (1993). **Equivalence factors: 0.81 $\mathrm{g}_{\text {acetic }} \cdot \mathrm{g}_{\text {propionic }}{ }^{-1} ; 0.68 \mathrm{~g}_{\text {acetic }} \cdot \mathrm{g}_{\text {butyric }}{ }^{-1} ; 0.59 \mathrm{~g}_{\text {acetic }} \cdot \mathrm{g}_{\text {valeric }}{ }^{-1} ; 0.46 \mathrm{~g}_{\text {acetic }} \cdot \mathrm{g}_{\text {heptanoic }}{ }^{-1}$.

\section{List of figures}

Figure 1. Accumulated methane yield related to initial VS of pig manure, pasteurized animal by-products and recovered glycerine.

571 Figure 2. Evolution of the organic loading rate (OLR) and hydraulic retention time 572 (HRT) along the different periods. Notes: Points denote the mean value of the two samples collected per week (also called weekly average). Lines denote the trend of each parameter, calculated as the mean value of every three consecutive "weekly average"

575 values.

576 Figure 3. Evolution of control parameters along the different periods: (a) Methane 577 production rate and $\mathrm{C} / \mathrm{N}$ ratio of the feeding. (b) Concentration of $\mathrm{N}$-related compounds in the digester: total Kjeldhal nitrogen of the inlet (inlet-TKN), total and free ammonia 
579 nitrogen in the outlet (outlet-TAN, outlet-FAN). Notes: Points denote the mean value

580 of the two samples collected per week (also called weekly average).

581 Figure 4. Stability indicators. (a) Evolution of propionic/acetic and alkalinity ratios

582 along the different periods. (b) Distribution of mean values per period of volatile fatty

583 acids (VFA). Note: Points denote the mean value of the two samples collected per week

584 (also called weekly average). Propionic/Acetic ratio, black points; Alkalinity ratio, grey

585 points. Bars: acetic, vertical lines; propionic, white; i-butyric, lean lines; n-butyric,

586 black squares; i-valeric, horizontal lines; n-valeric, grey; sum of total caproic and

587 heptanoic, black. 


\section{HIGHLIGHTS}

- A stepwise $\mathrm{C} / \mathrm{N}$ ratio increase was proposed as optimization strategy.

- Animal by-products binary blends led to synergic effect on methane production yield.

- A ternary co-digestion mixture with glycerin as a carbon source was proposed.

- Glycerin was a profitable co-substrate if enough buffer capacity was kept. 
Figure 1

Figure 1

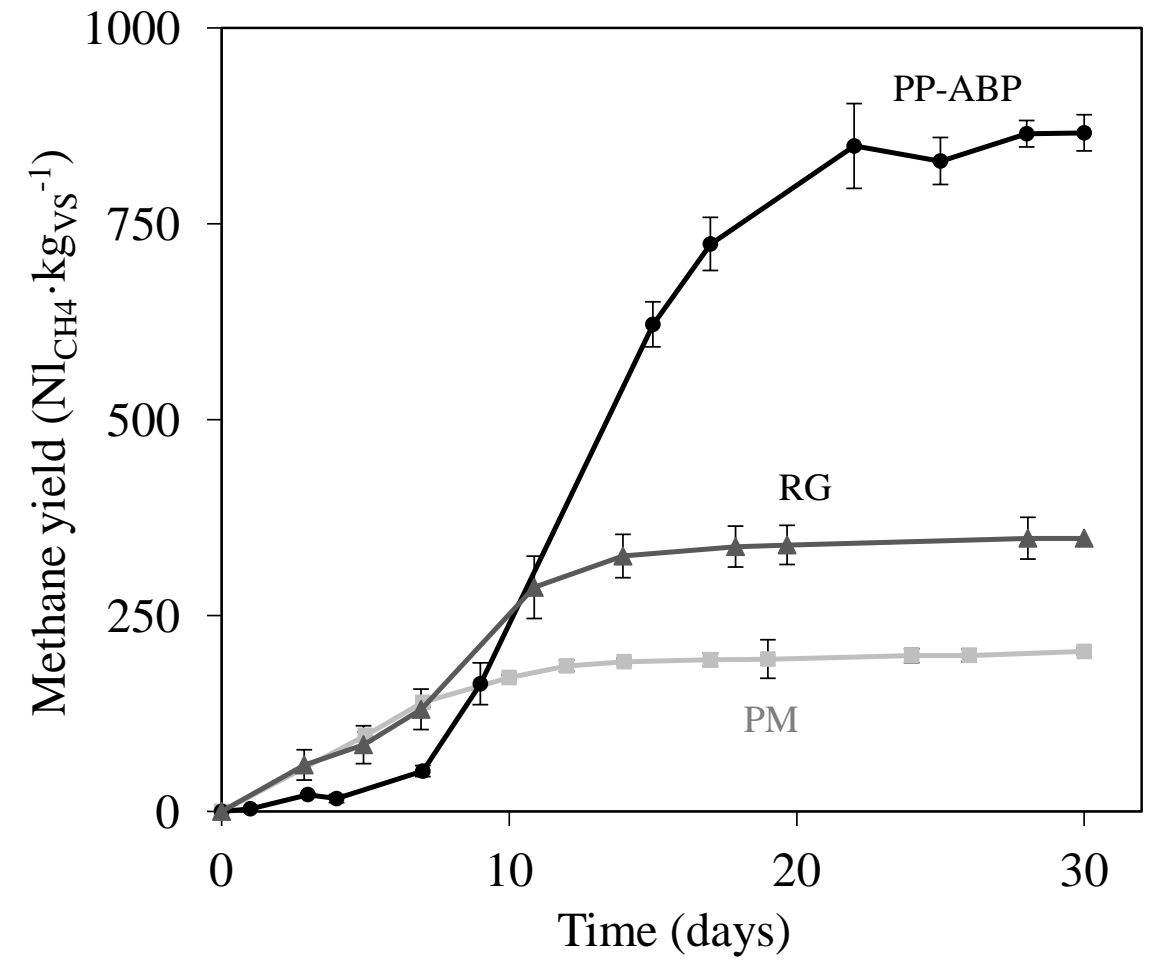


Figure 2

Figure 2

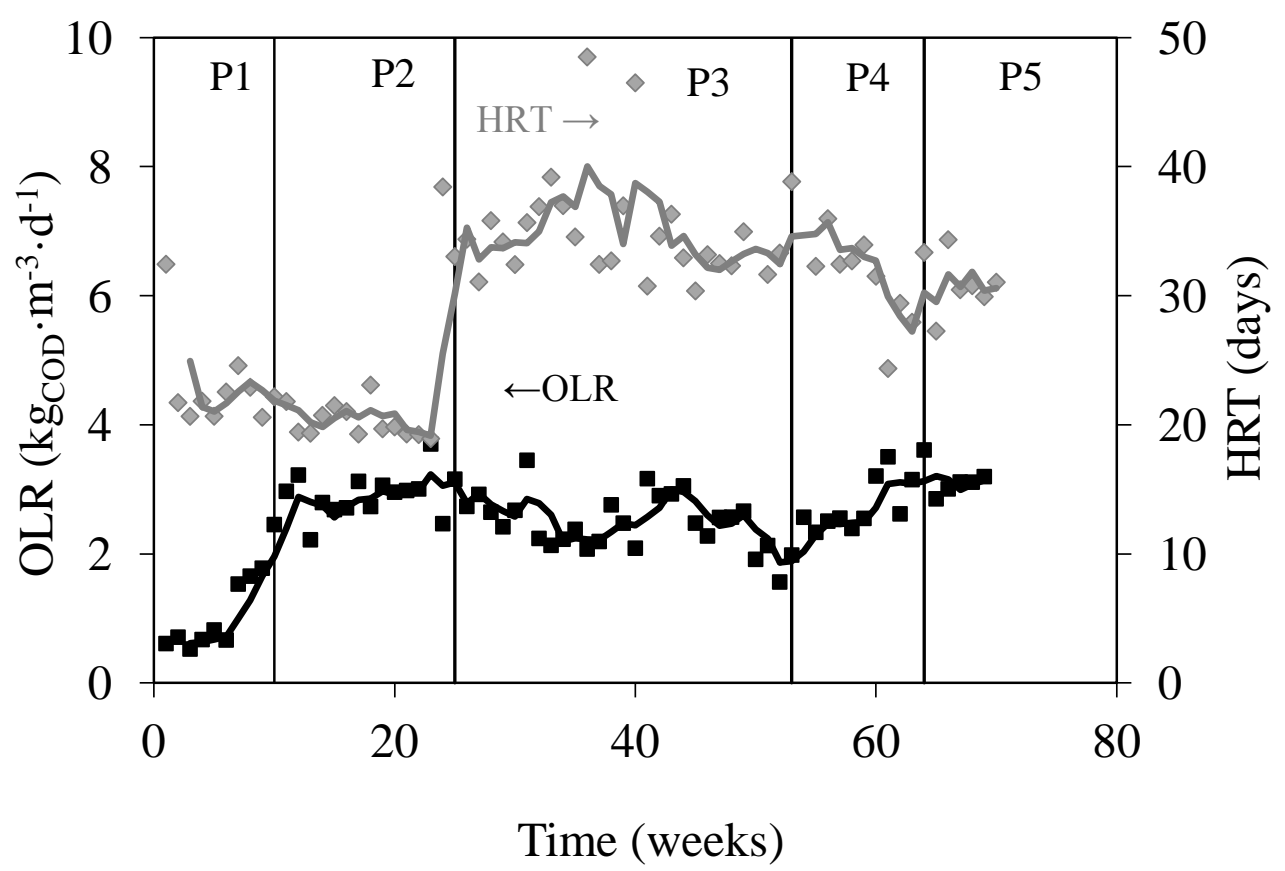


Figure 3

(a)

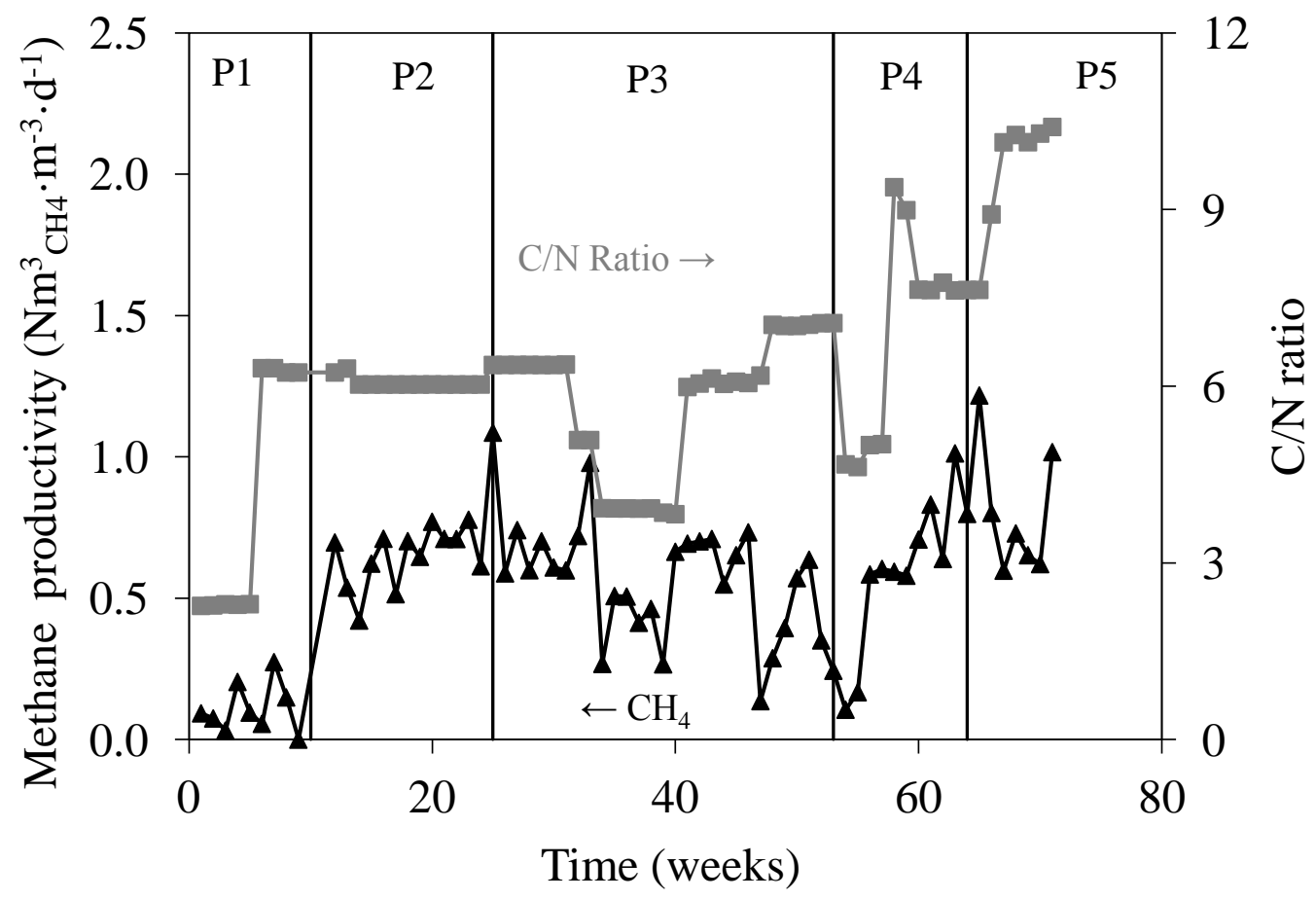

(b)

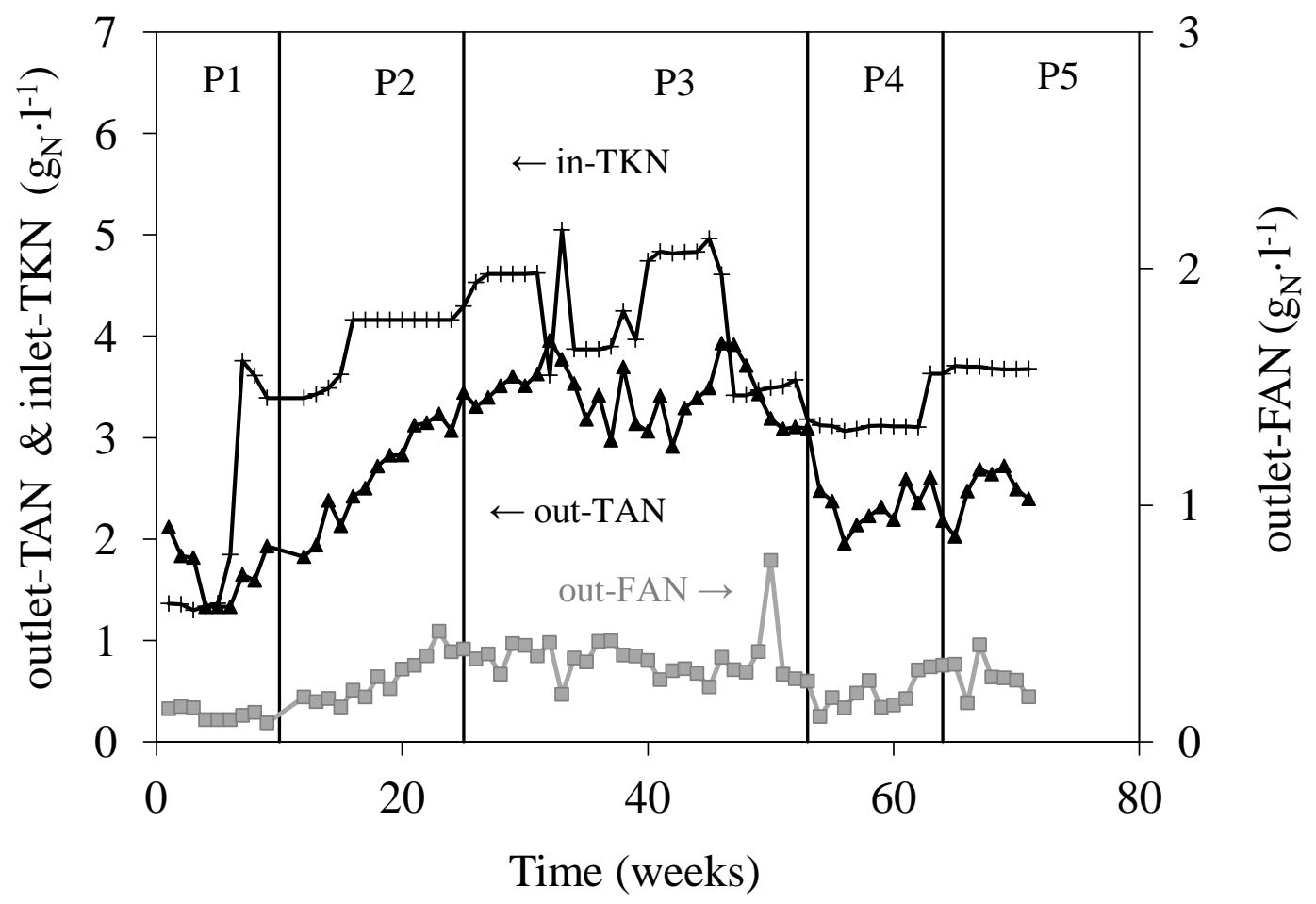


Figure 4

(a)

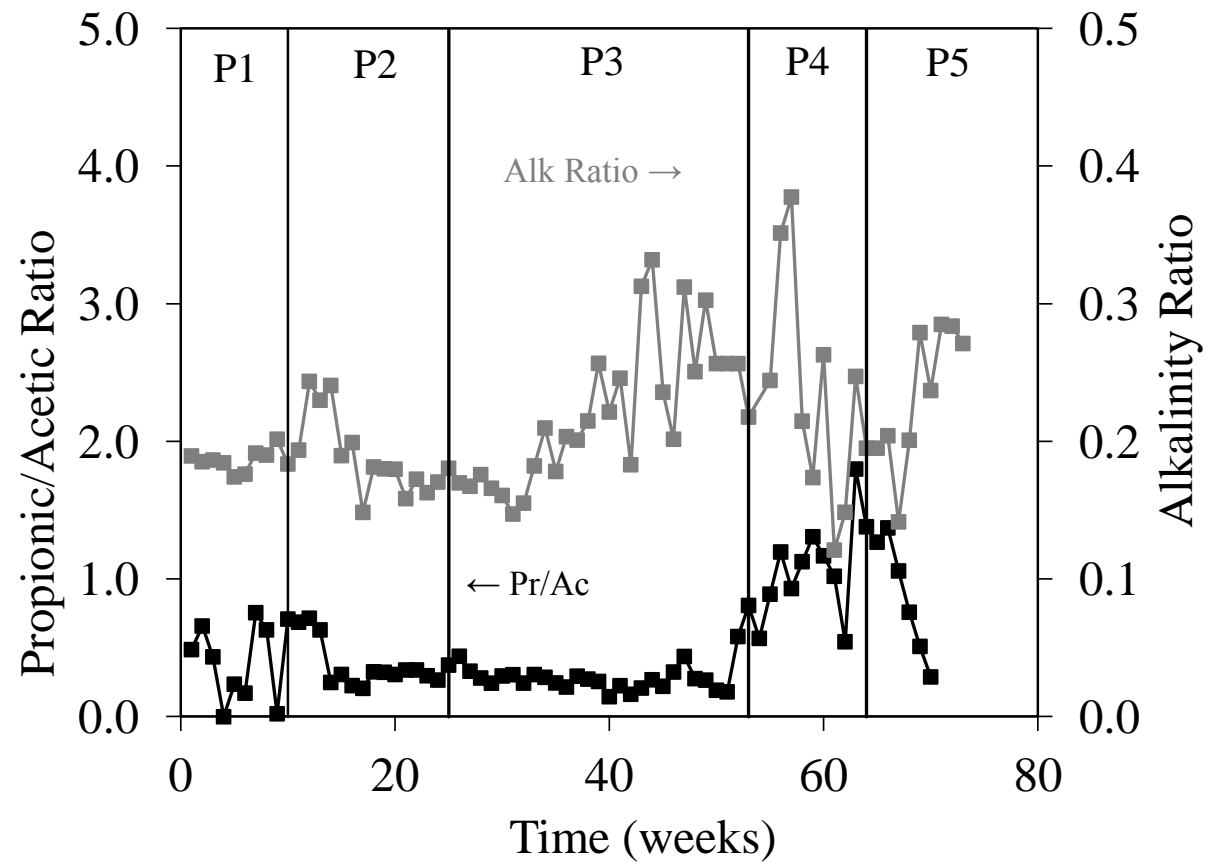

(b)

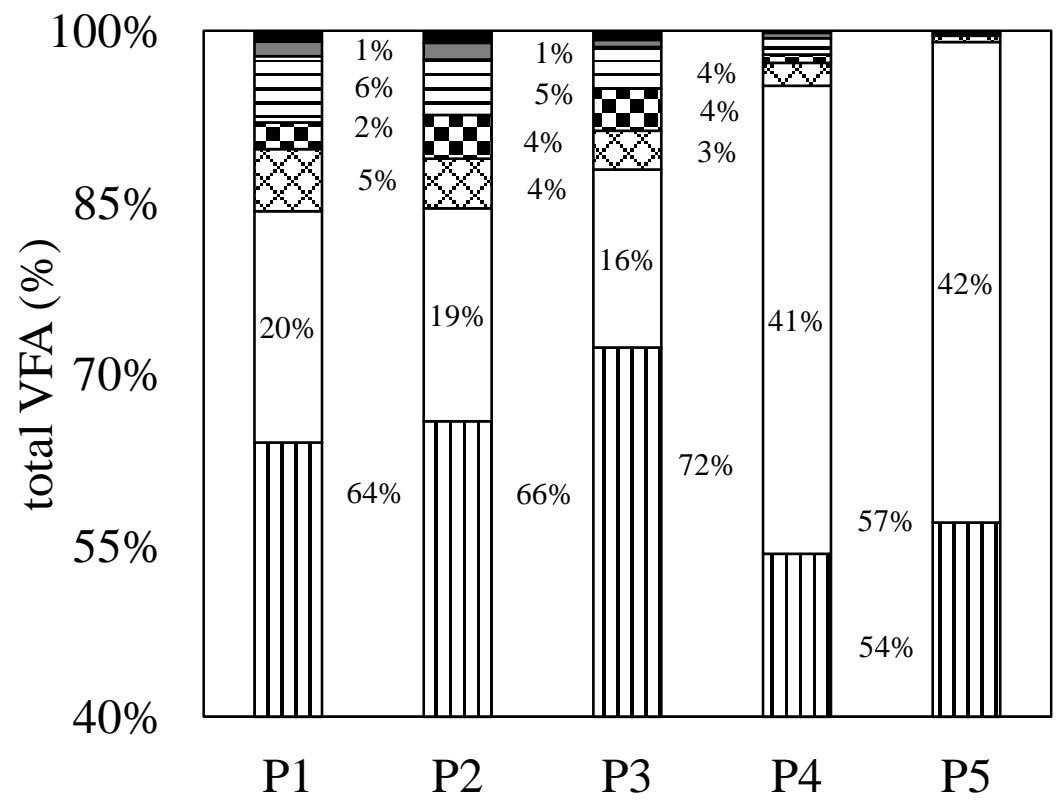


Table 1

\begin{tabular}{|c|c|c|c|c|c|}
\hline Parameter & PM & PM* & PP-ABP & PP-ABP* & RG \\
\hline $\mathrm{TS}\left(\mathrm{g} \cdot \mathrm{kg}^{-1}\right)$ & $36.7 \pm 10.2$ & $33.2 \pm 8.1$ & $552 \pm 3.1$ & $507 \pm 6$ & $926 \pm 0$ \\
\hline $\operatorname{VS}\left(\mathrm{g} \cdot \mathrm{kg}^{-1}\right)$ & $26.0 \pm 8.3$ & $21.7 \pm 6.7$ & $543 \pm 2.1$ & $499 \pm 30$ & $924 \pm 1$ \\
\hline $\mathrm{C} / \mathrm{N}\left(\mathrm{g} \cdot \mathrm{g}^{-1}\right)$ & $5.7 \pm 2.3$ & $5.3 \pm 1.3$ & $14.1 \pm 2.3$ & $15.7 \pm 2.2$ & $588 \pm 2$ \\
\hline $\mathrm{COD}\left(\mathrm{g} \cdot \mathrm{kg}^{-1}\right)$ & $45.4 \pm 7.1$ & $43.4 \pm 9.8$ & $1318 * *$ & $1078 \pm 81$ & $1517 \pm 13$ \\
\hline $\operatorname{VFA}\left(\mathrm{g}_{\mathrm{COD}} \cdot \mathrm{kg}^{-1}\right)$ & $8.3 \pm 4.9$ & $7.3 \pm 3.6$ & $2.5 \pm 0$ & $\mathrm{~nm}$ & $\mathrm{Nd}$ \\
\hline TAN $\left(g_{N} \cdot \mathrm{kg}^{-1}\right)$ & $2.5 \pm 0.3$ & $2.6 \pm 0.4$ & $1.5 \pm 0$ & $1.5 \pm 0.0$ & $\mathrm{Nm}$ \\
\hline $\operatorname{TKN}\left(\mathrm{g}_{\mathrm{N}} \cdot \mathrm{kg}^{-1}\right)$ & $3.4 \pm 0.3$ & $3.6 \pm 0.4$ & $19.2 \pm 2$ & $\mathrm{~nm}$ & $\mathrm{Nm}$ \\
\hline Protein $\left(\mathrm{g} \cdot \mathrm{kg}^{-1}\right)$ & $3.1 \pm 1.2$ & $5.7 \pm 1.2$ & $111 \pm 3$ & $\mathrm{~nm}$ & $\mathrm{Nm}$ \\
\hline Fat $\left(\mathrm{g} \cdot \mathrm{kg}^{-1}\right)$ & $\mathrm{nm}$ & $\mathrm{nm}$ & $363 \pm 1$ & $\mathrm{~nm}$ & $\mathrm{Nm}$ \\
\hline $\mathrm{S}-\mathrm{SO}_{4}{ }^{2-}\left(\mathrm{g} \cdot \mathrm{kg}^{-1}\right)$ & $\mathrm{nm}$ & $\mathrm{nm}$ & $\mathrm{nm}$ & $\mathrm{nm}$ & $1.7 \pm 0.1$ \\
\hline $\mathrm{AB}(\% \mathrm{COD})$ & $41.0 \pm 0.7$ & - & $94.3 \pm 3.0$ & - & $65.3 \pm 4.8$ \\
\hline Yield $\left(\mathrm{Nl}_{\mathrm{CH} 4} \cdot \mathrm{kg}_{\mathrm{VS}}{ }^{-1}\right)$ & $204 \pm 4$ & $209 * * *$ & $866 \pm 13$ & $809 * * *$ & $314 \pm 40$ \\
\hline $\mathrm{CH}_{4}(\% \mathrm{v} / \mathrm{v}$ biogas $)$ & $65 \%$ & - & $70 \%$ & - & $60 \%$ \\
\hline Yield $\left(\mathrm{Nm}_{\mathrm{CH} 4}^{3} \cdot \mathrm{t}^{-1}\right)$ & $6.0 \pm 0.1$ & $5.5 \pm 0.5$ & $476 \pm 7$ & $403 \pm 16$ & $202 \pm 29$ \\
\hline Yield $\left(\mathrm{Nm}^{3}\right.$ biogas $\left.\cdot \mathrm{t}^{-1}\right)$ & $9.2 \pm 0.2$ & - & $680 \pm 10$ & - & $337 \pm 48$ \\
\hline
\end{tabular}


Table 2

\begin{tabular}{|c|c|c|c|c|c|}
\hline \multirow{2}{*}{$\begin{array}{l}\text { Step } \\
\text { Period }\end{array}$} & \multirow{2}{*}{$\begin{array}{c}1 \\
\mathbf{P 1}\end{array}$} & \multicolumn{2}{|c|}{2} & \multicolumn{2}{|c|}{3} \\
\hline & & $\mathbf{P 2}$ & P3 & P4 & P5 \\
\hline \multicolumn{6}{|l|}{ Influent } \\
\hline PM:PP-ABP:RG (\%inlet VS) & 100:0:0 & $93: 7: 0$ & $64: 36: 0$ & $34: 50: 1$ & $35: 47: 1$ \\
\hline PM:PP-ABP:RG (\%inlet CODt) & 100:0:0 & $87: 13: 0$ & $52: 48: 0$ & $35: 51: 1$ & $34: 51: 1$ \\
\hline $\mathrm{C} / \mathrm{N}\left(\mathrm{g} \cdot \mathrm{g}^{-1}\right)$ & 6.3 & 6.1 & 5.9 & 8.0 & 10.3 \\
\hline $\operatorname{TAN}\left(\mathrm{g}_{\mathrm{N}} \mathrm{kg}^{-1}\right)$ & 2.69 & 3.08 & 2.62 & 1.61 & 2.14 \\
\hline \multicolumn{6}{|l|}{ Operational parameters } \\
\hline $\operatorname{HRT}(\mathrm{d})$ & 21 & 21 & 33 & 33 & 32 \\
\hline $\operatorname{OLR}\left(\mathrm{kg}_{\mathrm{COD}} \cdot \mathrm{m}^{-3} \cdot \mathrm{d}^{-1}\right)$ & 0.8 & 3.0 & 2.6 & 2.5 & 3.2 \\
\hline \multicolumn{6}{|l|}{ Control parameters } \\
\hline COD removal (\%) & $30 \%$ & $48 \%$ & $44 \%$ & $51 \%$ & $55 \%$ \\
\hline $\mathrm{CH}_{4}(\% \mathrm{v} / \mathrm{v})$ & $65 \%$ & $73 \%$ & $73 \%$ & $71 \%$ & $71 \%$ \\
\hline \multicolumn{6}{|l|}{ Yields: } \\
\hline $\mathrm{Nm}_{\mathrm{CH} 4}^{3} \cdot \mathrm{m}^{-3} \cdot \mathrm{d}^{-1}$ & 0.22 & 0.47 & 0.39 & 0.48 & 0.64 \\
\hline $\mathrm{Nm}_{\mathrm{CH} 4}^{3} \cdot \mathrm{kg}_{\mathrm{VSin}}{ }^{-1}$ & 0.15 & 0.35 & 0.43 & 0.38 & 0.38 \\
\hline $\mathrm{Nm}_{\mathrm{CH} 4}^{3} \cdot \mathrm{t}^{-1}$ & 3.6 & 9.7 & 13.6 & 16.0 & 18.7 \\
\hline$\alpha$ index & 0.7 & 1.4 & 1.0 & 0.7 & 0.7 \\
\hline $\operatorname{TAN}\left(\mathrm{g}_{\mathrm{N}} \cdot \mathrm{l}^{-1}\right)$ & 1.81 & 2.95 & 3.28 & 2.30 & 2.42 \\
\hline $\mathrm{FAN}\left(\mathrm{g}_{\mathrm{N}} \cdot \mathrm{l}^{-1}\right)$ & 0.13 & 0.33 & 0.31 & 0.14 & 0.11 \\
\hline Total VFA (\% effluent-COD)* & $1.5 \%$ & $3.6 \%$ & $2.8 \%$ & $4.2 \%$ & $1.9 \%$ \\
\hline Total VFA $\left(\mathrm{g} \text { acetic-eq } \cdot 1^{-1}\right)^{* *}$ & 0.3 & 1.8 & 2.3 & 1.7 & 1.9 \\
\hline $\mathrm{TA}\left(\mathrm{g}_{\mathrm{CaCO} 3} \cdot 1^{-1}\right)$ & 8.95 & 13.80 & 17.47 & 10.18 & 8.66 \\
\hline Alkalinity ratio & 0.19 & 0.19 & 0.22 & 0.22 & 0.24 \\
\hline $\mathrm{pH}$ & 7.8 & 7.7 & 7.9 & 7.8 & 8.0 \\
\hline Propionic to acetic ratio & 0.17 & 0.32 & 0.21 & 0.82 & 0.88 \\
\hline
\end{tabular}

